\title{
PENGARUH KEBISINGAN TERHADAP KADAR GLUKOSA DARAH MENCIT (Mus musculus L.) JANTAN
}

\section{EFFECTS OF NOISE ON BLOOD GLUCOSE LEVEL OF MALE MOUSE (Mus musculus L.)}

\author{
Feni Ismiyati ${ }^{1}$, Nuning Nurcahyani ${ }^{1}$, M. Kanedi ${ }^{1}$ \\ ${ }^{1}$ Jurusan Biologi FMIPA Universitas Lampung \\ e-mail : feni.ismi@yahoo.co.id \\ Jurusan Biologi FMIPA Universitas Lampung \\ Jl. Soemantri Brojonegoro No.1, Bandar Lampung, Lampung, Indonesia, 35145
}

\begin{abstract}
Abstrak
Kebisingan adalah salah satu faktor stres bagi manusia. Stress karena bising dapat mempengaruhi sistem endokrin sehingga membahayakan kesehatan. Tujuan penelitian ini adalah untuk membuktikan bahwa kebisingan dapat mempengaruhi kadar glukosa darah mencit (Mus musculus L.) jantan. Penelitian ini telah dilaksanakan pada bulan Mei - Juni 2013 di Laboratorium Zoologi Jurusan Biologi FMIPA Universitas Lampung menggunakan Rancangan Acak Lengkap (RAL) dengan 1 kelompok kontrol dan 4 kelompok diberi perlakuan kebisingan dengan intensitas kebisingan 85-90 dBA dengan waktu pemaparan 6, 8, 10 dan 12 jam/hari selama 21 hari. Tiap kelompok percobaan terdiri atas 5 individu mencit. Parameter yang diamati dalam penelitian ini adalah kadar glukosa darah mencit. Hasil pengamatan di analisis menggunakan analisis statistik deskriptif. Hasil penelitian menunjukkan bahwa kebisingan dengan intensitas 85-90 dBA meningkatkan kadar glukosa darah mencit (Mus musculus L.) jantan. Rerata kadar glukosa darah mencit jantan yang diberi perlakuan kebisingan lebih tinggi dibandingkan dengan kontrol dan kadar glukosa darah tertinggi pada pemaparan $12 \mathrm{jam} / \mathrm{hari}$ adalah $194 \mathrm{mg} / \mathrm{dL}$.
\end{abstract}

Kata Kunci: Kebisingan, glukosa darah, mencit (Mus musculus L.) jantan.

\begin{abstract}
Noise is one of stress factors for human. Stress caused by noise affects endocrine system which presunably hazard to human health. The objective of the research was to prove that noise can affect the blood glucose level of male mouse (Mus musculus L.). The research was conducted from May June 2013 in Zoology Laboratory, Biology Department, Mathematics and Natural Sciences Faculty, University of Lampung. The research used completely randomized design with 1 group was control group and 4 groups were treated by noise with 85-90 dBA noisy level at different time of exposure (6, 8,10 , and 12 hours/days) as long as 21 days. Each group, contained five individuals mice used as replication. The blood glucose levels in male mouse were analyzed using descriptive statistic. The result shows that all the treatment group given noise with intensity of 85-90 dBA increased blood glucose level in male mouse (Mus musculus L.). The average of blood glucose level of male mouse treated by noise is higher than control and the highest blood glucose level at 12 hours/days exposure was $194 \mathrm{mg} / \mathrm{dL}$.
\end{abstract}

Key Word: Noise, blood glucose, male mouse (Mus musculus L.).

\section{PENDAHULUAN}

Kebisingan merupakan bunyi yang tidak diinginkan karena dalam tingkat dan waktu tertentu dapat menimbulkan gangguan kesehatan manusia dan kenyamanan lingkungan (KepMenLH No.48 Tahun 1996). Menurut Dirjen P2M dan PLP Departemen Kesehatan RI (1993), kebisingan adalah terjadinya bunyi yang tidak diinginkan sehingga mengganggu dan atau dapat membahayakan kesehatan.
Bising merupakan salah satu faktor stres bagi individu, dan dapat berdampak buruk pada kesehatan apabila terjadi terus menerus dan melampui daya adaptasi individu. Keadaan bising dapat mengakibatkan gangguan yang serius dan mempengaruhi kondisi fisiologis dan psikologis. Bahaya yang diakibatkan oleh kebisingan ini tergantung dari tingkat kebisingan dan lama pemaparannya. Tingkat kebisingan di atas 70 $\mathrm{db}$ (desiBel) dapat berkontribusi terhadap gangguan kardiovaskuler (Inayah, 2008). 
Di Indonesia nilai ambang batas kebisingan ditetapkan sebesar $85 \mathrm{db}$ pada skala A (dBA), selama 8 jam kerja (Surat edaran Menteri Tenaga Kerja No 51/1999). sedangkan baku mutu kebisingan di daerah industri sesuai dengan Keputusan Menteri Negara Lingkungan Hidup No. KEP-48/MENLH/11/1996 adalah 70 dBA.

Menurut Marpaung (2006), pemaparan Kebisingan sebesar 90-95 dBA dan 100-105 dBA dapat meningkatkan kadar kortisol dalam darah tikus putih. Hal tersebut terjadi karena intensitas kebisingan yang tinggi serta terjadi terus menerus dapat menjadi penyebab stres yang mempengaruhi hipotalamus dan akhirnya mengganggu sistem kerja kelenjar endokrin. Akibat dari stres bising hipotalamus secara langsung akan mengaktifkan sistem saraf simpatis, mengeluarkan Corticotropin Releasing Hormone $(\mathrm{CRH})$ untuk merangsang Adeno Corticotropin Hormone (ACTH) dan kortisol serta menyebabkan sekresi epinephrine. Hormon-hormon yang disekresikan pada saat stres berpotensi meningkatkan kadar glukosa darah (Sherwood, 1996)

\section{BAHAN dan METODE}

Penelitian ini dilaksanakan di Laboratorium Zoologi Jurusan Biologi FMIPA Universitas Lampung dari bulan Mei sampai dengan Juni 2013, menggunakan 25 ekor mencit jantan dengan berat badan 30-35 gram dan umur 3-4 bulan. Sebelum diberi perlakuan, mencit terlebih dahulu diaklimatisasi selama satu minggu. Kebisingan yang digunakan bersumber dari aplikasi souncard scope yang diberi tambahan pengeras suara dengan intensitas 85-90 dBA. Penelitian ini menggunakan Rancangan Acak Kelompok, dengan menggunakan 5 kelompok dan pada masing-masing kelompok terdapat 5 individu mencit sebagai ulangan. Kelompok pertama digunakan sebagai kontrol (P0), kelompok kedua diberi paparan kebisingan selama 6 jam/hari (P1), kelompok ketiga diberi paparan kebisingan selama 8 jam/hari (P2), kelompok keempat diberi paparan kebisingan selama 10 jam/hari (P3) dan kelompok kelima diberi paparan kebisingan selama 12 jam/hari (P4). Setelah mencit diberi perlakuan selama 21 hari, pada hari ke-22 dilakukan pengambilan darah untuk diukur kadar glukosa darahnya. Langkah awal pada proses pengambilan darah mencit ini adalah melakukan pembiusan mencit menggunakan kloroform. Setelah dibius kemudian ekor mencit dibersihkan menggunakan alkohol $70 \%$, dan ujung ekor dipotong dengan menggunakan gunting. Tahap selanjutnya adalah pengukuran kadar glukosa darah menggunakan glukometer. Tetesan darah yang pertama dibuang dan tetesan darah yang ke- dua diteteskan pada strip uji glukometer sekali pakai. Kadar glukosa darah diukur setelah 5 detik dan dinyatakan dalam satuan $\mathrm{mg} / \mathrm{dL}$.

\section{HASIL dan PEMBAHASAN}

Berdasarkan hasil perhitungan menunjukkan bahwa intensitas kebisingan 85-90 dBA dapat meningkatkan kadar glukosa darah mencit jantan. Rerata kadar glukosa darah kelompok yang diberi perlakuan mangalami peningkatan jika dibandingkan dengan kontrol (Gambar 1).

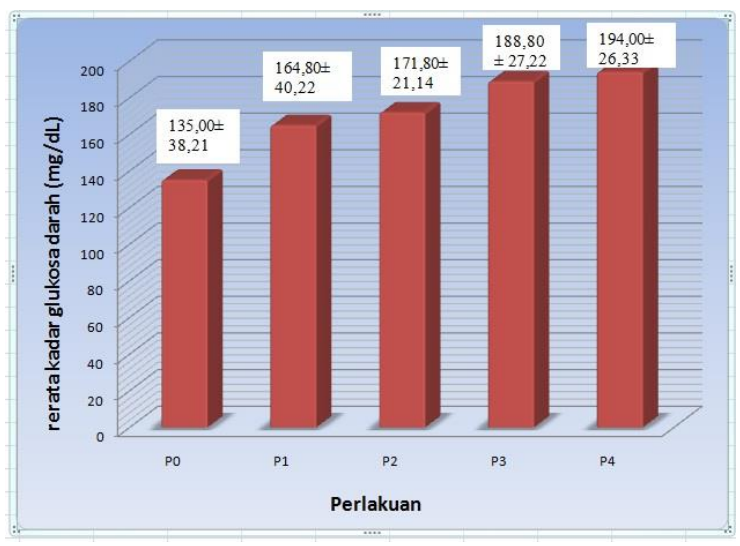

Gambar 1. Rerata Kadar Glukosa Darah mencit Jantan

Berdasarkan hasil pengamatan diduga semakin lama waktu pemaparan kebisingan maka akan semakin berbahaya bagi fisiologis mencit, karena kebisingan yang terlalu lama dengan intensitas yang tinggi akan meningkatkan kadar glukosa dalam darah. Seperti yang dikemukakan oleh Marpaung (2006), bahwa bising merupakan pemicu stres bagi individu, dan stress akibat bising dapat mempengaruhi sistem endokrin. Keadaan stress menyebabkan individu merasa terancam sehingga hipotalamus akan mengaktifkan medulla adrenal melalui impuls saraf dan korteks adrenal melalui sinyal hormonal. Pada respon stress jangka pendek medulla adrenal akan mensekresikan hormon katekolamin yaitu epinephrine dan norepinephrin dan kedua hormon tersebut berfungsi untuk merombak glikogen menjadi glukosa sehingga terjadi peningkatan kadar glukosa darah. Pada respon stress jangka panjang korteks adrenal akan mensekresikan glukokortikoid yang berpengaruh untuk merombak protein dan lemak menjadi glukosa yang menyebabkan peningkatan kadar glukosa darah (Campbell dkk., 2004).

Hasil penelitian menunjukkan bahwa kebisingan dengan intensitas 85-90 dBA berpengaruh terhadap kadar glukosa mencit jantan, hal ini sesuai dengan hasil penelitian Marpaung (2006), yang menyatakan bahwa stres akibat 
kebisingan dapat meningkatkan kadar kortisol dalam darah tikus jantan karena hipotalamus akan mengaktifkan sistem saraf simpatis, mengeluarkan $\mathrm{CRH}$ untuk merangsang sekresi ACTH dan kortisol. Smeltzer dan Bare (2008), menyatakan bahwa apabila kadar kortisol meningkat maka kadar glukosa darah juga akan meningkat karena kortisol akan meningkatkan konversi asam amino, asam laktat dan asam piruvat menjadi glukosa di hati melalui proses glukoneogenesis. Kebisingan terbukti memiliki dampak yang buruk bagi kesehatan, hal ini sesuai dengan hasil penelitian Ghupta dan Ghatak (2011), yang menyatakan bahwa kebisingan dapat menyebabkan sakit kepala, gelisah, gangguan pendengaran, gangguan kardiovaskuler, dan insomnia. Menurut hasil penelitian Singhal dkk. (2009) kebisingan industri merupakan salah satu faktor penyebab hipertensi karena meningkatkan tekanan darah pada pekeja. Hasil penelitian Fezil dkk. (2013) juga menunjukkan bahwa stres akibat kebisingan ini dapat meningkatkan tekanan darah, denyut nadi, perubahan insulin serta glukosa darah sehingga dapat menyebabkan hipertensi dan kemungkinan dapat menjadi faktor penyebab diabetes.

Menurut Hastututi dkk. (2003) stress akibat perubahan suhu dingin secara mendadak dapat meningkatkan kadar glukosa darah pada ikan gurami. Selain disebabkan oleh stres peningkatan glukosa darah juga dapat disebabkan karena asupan kalori yang berlebihan (Price dan Wilson, 2002), kurang berolah raga, bertambahnya jumlah makanan yang dikonsumsi, pertambahan berat badan dan usia, serta dampak perawatan dari obat, misalnya steroid (Fox dan Kilvert, 2010).

Nilai rerata kadar glukosa darah pada perlakuan pemaparan kebisingan 6 dan 8 jam/hari mengalami peningkatan namun masih berada pada rentang yang normal yaitu $164,80 \mathrm{mg} / \mathrm{dL}$ pada pemaparan 6 jam/hari dan $171,80 \mathrm{mg} / \mathrm{dL}$ pada pemaparan 8 jam/hari. Diduga perlakuan pemaparan 6 dan 8 jam/hari dikategorikan pada batas normal sehingga cenderung tidak berpengaruh secara fisiologis. Hal ini sesuai dengan Keputusan Menteri Tenaga Kerja No $51 / 1999$ yang menetapkan nilai ambang batas kebisingan adalah 85 dBA selama 8 jam. Diduga apabila pemaparan kebisingan melebihi 8 jam/hari dengan intensitas lebih dari 85 dBA maka akan memberikan dampak yang buruk bagi kesehatan seperti gangguan fisiologis, psikologis, pendengaran, dan gangguan kesehatan lainnya.

Menurut Kusumawati (2004), kadar glukosa darah mencit normal adalah berkisar antara 62,8$176 \mathrm{mg} / \mathrm{dL}$. Pada pemaparan kebisingan 10 dan 12 jam/hari rerata kadar glukosa darahnya melebihi batas normal yaitu dengan nilai rerata kadar glukosa darah $188,80 \mathrm{mg} / \mathrm{dL}$ pada pemaparan $10 \mathrm{jam} / \mathrm{hari}$ dan $194 \mathrm{mg} / \mathrm{dL}$ pada pemaparan 12 jam/hari. Diduga pada pemaparan 10 jam/hari dan 12 jam/hari tubuh tidak mampu untuk mempertahankan keseimbangan fungsi fisiologisnya sehingga glukosa darah meningkat. Kemungkinan apabila individu terpapar lebih dari 12 jam/hari dengan intensitas yang tinggi maka akan memberikan dampak yang lebih buruk bagi kesehatan.

\section{KESIMPULAN}

Dari penelitian ini dapat disimpulkan bahwa Rerata kadar glukosa darah kelompok yang diberi perlakuan kebisingan dengan intensitas 85-90 dBA lebih tinggi dibandingkan dengan kontrol dan rerata kadar glukosa darah tertinggi terdapat pada pemaparan kebisingan 12 jam/hari yaitu $194 \mathrm{mg} / \mathrm{dL}$.

\section{DAFTAR PUSTAKA}

Campbell, N.A, B.R. Jane, dan G.M. Lawrence. 2004. Biologi, (Terjemahan): Manalu, W. Edisi kelima jilid III. Erlangga. Jakarta.

Dirjektorat Jendral Pemberantasan Penyakit Menular dan Penyehatan Lingkungan Pemukiman Departemen Kesehatan RI. 1993. Pelatihan Petugas Pengawas Tingkat Kebisingan Model III. Jakarta.

Fezil M., M. P. Narmadha, dan B. Benson. 2013. Influence of Occupational Noise on Insulin, Blood Glucose, Homocysteine, Blood Pressure and Heart Rate International Journal of Pharmaceutical and Clinical Science 3 (2):14-19.

Fox, C dan A. Kilvert. 2010. Bersahabat dengan Diabetes Tipe Dua. Penebar Plus. Depok.

Ghupta, S. dan C. Ghatak. 2011. Environmental Noise Assessment and its Effect on Human Health in an Urban Area. International Journal of Environmental Sciences Volume 1, No 7 :1954-1964.

Hastuti,S., E. Supriyono, I. Mokoginta, dan Subandiyono. 2003. Respon Glukosa Darah Ikan Gurami (Osphronemus gouramy, LAC.) Terhadap Stres Perubahan Suhu Lingkungan. Jurnal Akuakultur Indonesia. Indonesia 2(2): 73-77.

Inayah. 2008. Pengaruh Kebisingan terhadap Jumlah Leukosit Mencit BALB/C. Universitas Diponegoro. Semarang.

Keputusan Menteri Negara Lingkungan Hidup. 1996. Kep 48/MENLH/11/1996 tentang Baku Tingkat Kebisingan. Jakarta. 
Keputusan Menteri Tenaga Kerja No. 51 tahun 1999. Nilai Ambang Batas Iklim Kerja dalam Kebisingan di Tempat Kerja. Departemen Tenaga Kerja dan Transmigrasi. Jakarta.

Kusumawati, D. 2004. Bersahabat dengan Hewan Coba. Gadjah Mada University Press. Yogyakarta.

Marpaung, S.S. 2006. Pengaruh Kebisingan Intensitas Tinggi terhadap Kadar Kortisol pada Tikus Jantan. Majalah kedokteran Nusantara Volume 39 No 32 : 94-99.
Price, S.A dan L.M. Wilson. 2002. Patofisiologi Konsep Klinis Proses Penyakit. EGC. Jakarta.

Sherwood, L. 1996. Human Physiology : from cells to systems. Thomson Publishing Inc. Virginia.

Singhal, S., B.Yadav, S.F. Hasmi, dan M.D Muzammil . 2009. Effects of Workplace Noise on Blood Pressure and Heart Rate. Biomedical Research 20 (2): 122-126.

Smeltzer, S.C dan B.G Bare. 2008. Buku Ajar Keperawatan Medical Bedah. EGC. Jakarta. 